\title{
RNA: Life's Indispensable Molecule, by James E. Darnell. 2011. Cold Spring Harbor Laboratory Press. ISBN: 978-1-936113-19-4.
}

There have been many books about the advent and ascent of molecular biology, both as science and as tribal affinities and rivalries (Olby 1974, 2009; Dubos 1976; Judson 1979; Crick 1988; Jacob 1988; Kay 1993, 2000; Echols 2001; Holmes 2001; Maddox 2002; Ullmann 2003). Those just cited are, in my view, some of the most accurate and evocative accounts. But it is a remarkable fact that even though RNA rose up and took over everything else in the origin and continuing operation of life (at least here on our planet), no author has taken on, in broad perspective, the history and outcomes of RNA science, with the exception of an engaging book on RNA in the pre- and early post-biotic eras and current studies aimed at rekindling those molecules and their chemical properties (Yarus 2010). (I am referring to sole-authored books, while fully recognizing the importance of multi-authored ones, of which Gesteland et al. 2006 is the gold standard.) And to be sure, earlier books on RNA (e.g., Petermann 1964; Sirlin 1972) were state-of-the-art accounts at the time, written by pioneers, but are not part of the modern canon. But now we have a book on RNA in full form that is sui generis. What has created this happy state of affairs? Jim Darnell has weighed in.

At first blush, we would think anyone in the current (i.e., living) RNA science pantheon could write a book like this, but once one takes a look and sees the richness of erudition, the poignancy of detail, the measured nuances, and-most of all-his elegant writing, combined with the underlying perspective of history, I cannot think of anyone in our RNA community who could have done it more attractively. A skeptic might counter: "Yes, but this is what a senior statesperson can do in their later years." Well, Jim Darnell continues to run a productive laboratory, so no one should view the extraordinary accomplishment this book represents as something done when the author was in full retirement-hence, all the more admiration for the accomplishment. I was with him throughout the 2010 Cold Spring Harbor Annual Symposium (Molecular Evolution), and his

Article published online ahead of print. Article and publication date are at http://www.rnajournal.org/cgi/doi/10.1261/rna.2939711. astute questions and conversations revealed that his legendary intellectual agility is in fine form.

This undertaking was admittedly large in sheer scientific scale, and there was also the challenge of how to tell it all as epistemology but not have readers doze off when experiments from the early days were described. Should one start with dry chemical history ("yeast nucleic acid," "pentose nucleic acid"- and those studies were, indeed, literally "dry" as the preps often started as dried yeast) or maybe instead start with the late 1930s/early 1940s findings that cytoplasmic basophilia seen with certain stains as well as a high 260-nm absorbance observed in the cytoplasm of intensely protein-secreting cells could both be eliminated by RNase? Or would one instead throw down the gauntlet and just state, as a given, that a hopeful RNA molecule got built one day amidst some foundational clay (as a heterogeneous catalyst, not a reactant) via a condensation reaction between cyanide and formaldehyde or whatever, and then the product (still waiting for a glycosidic bond to come) somehow got lipid around it, and "Well, dear readers, this is why you should buy and read my book on everything about RNA"? The author, a man of exquisite taste, took none of those used-car-salesperson approaches as a selling point, nor did his publisher. (The subtitle's word "Indispensable" is profoundly apt, and also well designed as marketing.)

In an author's note, Darnell outlines his career with evocative remembrances of many extraordinary mentors, all of whom instantly recognized his talent. (I am saying that-the author is more modest.) Surprisingly not mentioned is his first research experience, in the laboratory of Robert Glaser at Washington University, where the young Darnell did some outstanding research in a relatively short time and where a bond between him and Glaser, a pioneer of experimental medicine, was forged that endures up to today. There follows an Introduction in which the author lays out his intent (this short section is itself a preview showcase of his elegant writing style). He informs us that he will present what we know about RNA and how we got to know it, with the historical axis enriching the story but not detracting or distracting from it. In this avowed core mission, the author has succeeded 
in every respect, and this is what makes this book so special.

Chapter 1 takes up the history of research on macromolecules (viz., proteins and DNA) before RNA was on the investigative scene as either a biochemical substance or an active agent of biology. This might seem an odd way to start the book, but it really works. The notion of biological molecules of very large mass, how they could be corralled and studied, even as crystals when the muses smiled, is presented with engaging reach. (In the first encounters with RNA, in the pre-coding era, its molecular weight was not even remotely considered. Francis Crick, who predicted something akin to transfer RNA shortly before its discovery, thought it should be only $\sim 3$ nt.) I found myself deeply absorbed in this chapter. None of the material was unfamiliar to me, yet the way the author presented it was very engaging.

The next chapter describes the 1950s era of RNA science. Those between the ages of 70 and 90, and a few younger, know that interest in RNA at that time had arisen in large part from the presence of RNA in plant viruses, discovered for tobacco mosaic virus in 1935 by Wendell Stanley. This was a transformative era and rooted later discoveries such as when Dan Brown in Alex Todd's laboratory solved the $5^{\prime}$-to-3' polarity of ribose linkages in RNA. Darnell also brings in the discovery of the metabolic instability of phageinduced RNA (a kinetic property later exploited in the discovery of messenger RNA, vide infra), the description of microsomes (pieces of what later were recognized to arise from the endoplasmic reticulum), and the pioneering work by Paul Zamecnik's group on cell-free protein synthesis and their discovery of transfer RNA. He describes these steps in accurate and enjoyable style, and, having just reviewed the Zamecnik group's work (Pederson 2010, 2011), I found Darnell's account to be spot-on insightful. This chapter moves on engagingly to the monumental discovery of the operon and its regulation by Jacob and Monod, including the famous PaJaMo experiment, known today more for its clever acronym than the powerful role Arthur Pardee played in the discovery of messenger RNA. In fact, he envisioned it before almost anyone (see Pardee 1958). My only complaints about this chapter are in the context of Darnell's avowed desire for historical depth. I thought the pursuit of RNA secondary structure was not developed well, even though this was among the most vibrant and often perplexing eras of early biophysical work on RNA. Second, his description and emphasis of steps on the path to the discovery of messenger RNA are, in my opinion, just a bit ill-balanced. He mentions an extremely important and enabling finding (Nomura et al. 1960) only in a single sentence and then describes the "clincher" (Brenner et al. 1961) in greater detail. The Brenner et al. experiments were sterling in conception and execution and thus need no embellishment beyond their elegance and powerful suasion. But Darnell then relegates the contemporaneously pub- lished experiments from Jim Watson's laboratory (Gros et al. 1961) to a single sentence. There is a real dialectical asymmetry in the design and cogency of the two sets of experiments, and there is more mystique in the roles of all the players than is widely known. Had I written this chapter, I would have developed both papers, as well as Nomura's, in much more detail. There are other important features of the path to the discovery of messenger RNA, such as Jacques Monod's surprising and inexplicable opposition to the idea. But I suppose it is fair to ask if Darnell should have been expected to pen a formal history-of-science treatment of all of the details and nuances in the mRNA discovery chain.

In Chapter 3, Darnell takes up the discovery of the genetic code, the Howard Dintzis experiment (famous almost from the day it was published), the discovery of RNA polymerase (by Sam Weiss and a few months later by Audrey Stevens and Jerard Hurwitz, all working independently), and the race for and discovery of the lac and $\lambda$ repressors. This era is described as the exciting confluence of discoveries that it was. My only complaint is that nowhere is the name of the person who discovered the polynucleotide polymerase mentioned. Marianne GrunbergManago is the person whose name should always be known for that discovery, one that was the key to getting the first codons. Darnell is not gender-blind and was a staunch supporter of women scientists early in his career and all throughout (the same cannot be said of Severo Ochoa) and will instantly recognize this unintended omission.

Notwithstanding the erudition and eloquence of the previous chapters, in Chapter 4 ("Gene Expression in Mammalian Cells") the author hits an even higher stride, this being his own research career entry point and the pivot for his subsequent trailblazing career. He presents a stirring account of how mammalian cell culture got going as a science, and as one familiar with this history, I can attest to his timeline and dramatis personae as being accurate in atomic detail. The use of cultured human cells, most notably HeLa cells, and Darnell's prescient interest at the time in the potential of animal cell viruses as tools to discover principles of cell regulation (forged, I suspect, when he trained with Glaser) are what led him to his landmark discoveries on eukaryotic RNA biosynthesis. He had later trained with Harry Eagle, a pioneer of virology and mammalian cell culture, at the $\mathrm{NIH}$, and he appreciatively paints the necessary cell biological context (in Blake bottles and other glass flasks when "in vitro" was earning its name) that made possible many of the key advances in the eukaryotic RNA field. In historical terms, I found Darnell's linking of mammalian cell culture advances to the advent of the eukaryotic RNA field to be one of his most effective strokes.

Also in the animal virus vector of the RNA field, this chapter conveys how Jonathan Warner, then a graduate student in Alex Rich's lab at MIT, discovered polyribosomes by translating poliovirus RNA (a messenger RNA, as 
picornavirus genomic RNAs always are) in a rabbit reticulocyte lysate available to him one floor below. This reminds us of the times when openness and sharing of ideas and results were the norm, as at MIT when Darnell was there (which he could have expanded on as a theme).

Continuing in Chapter 4, Darnell then squarely tackles the awkward era in which many laboratories tried to understand the Walpurgis Night of large nuclear RNAs and their relationship to messenger RNA biosynthesis. His lab was among the first to observe these transcripts, in studies involving Klaus Scherrer and a gifted technician, Harriet Latham (later to rise, after her $\mathrm{PhD}$ and post doc, as the retrovirologist Harriet Robinson). These experiments provided evidence of the possible precursor-product relationship of these large nuclear RNA molecules to ribosomal and messenger RNA. This evidence was considered compelling by most but met with intense opposition in some quarters, notably by Henry Harris in the United Kingdom (Harris 1963). While Darnell and other leading nuclear RNA scientists in the USA resented Harris's polemical counterarguments, from a history of RNA perspective the author might have mentioned this distaff moment, at least en passant.

Darnell was also at the forefront of key advances later, viz., the codiscovery of poly $(\mathrm{A})$, the greater sequence complexity of nuclear RNA versus cytoplasmic mRNA, and other catalytic findings. For example, his laboratory incisively got the idea that tracing the newly discovered $5^{\prime}$ cap out of the nuclear RNA and into mature cytoplasmic mRNA would likely resolve the complex hnRNA-mRNA kinetic and biosynthetic pathway. All of these advances are presented in a very engaging way, as only a master of a subject can do. Eukaryotic RNA biosynthesis has not been covered as well since Ben Lewin's powerful treatment (Lewin 1980). Continuing in this chapter, the author takes up the RNA-directed (i.e., RNase P) processing of pre-tRNA, self-splicing RNAs, and the three RNA polymerases and their transcription targets, and closes with a pitch for run-on transcription assays. The latter especially appealed to me as I consider run-on transcription to be among the most important and yet often unheralded techniques in the eukaryotic gene expression field. This said, there are two other aspects of this chapter with which I would quarrel just a bit. The discovery of the adenovirus late mRNA tripartite leader's nonpairing with the virus's genomic DNA, made nearly contemporaneously at Cold Spring Harbor and at MIT, which was the key step to the discovery of mRNA splicing, has elements of complexity that Darnell knows but does not divulge. He may have felt that these details of the discovery were beyond the scope of his book, yet he did pledge a historical undercarriage. Similarly, the idea that the U1 small nuclear RNA's $5^{\prime}$ end is complementary to pre-mRNA $5^{\prime}$ splice sites, most effectively advanced by Joan Steitz and colleagues in a monumental paper, with real data (Lerner et al. 1980), had been previously floated (in very general terms) by the late Lennart Philipson from the floor at a meeting and in print by Randolph Wall. Neither of these antecedents came close to the cogency of the paper by Steitz and colleagues, but, again, the author's promise to delve into history falls a bit short here and there. Another dimension not mentioned is that the $30 \mathrm{~S}$ nuclear RNP particles that were a key part of the Lerner et al. paper had had a rather shaky reputation for many years, even though by 1980-1981 these particles were taking on a more respectable look (Pederson 1974; Pederson and Davis 1980; Munroe and Pederson 1981; Pederson and Munroe 1981; Steitz and Kamen 1981). The Lerner et al. paper not only presented a compelling case for the U1 snRNP's $5^{\prime}$-end interaction with pre-mRNA, it also solidified many observers' confidence in the RNP form of pre-mRNA, and this point could have been emphasized further. I also think Darnell could have carried the snRNP-mRNA splicing findings further as a timeline. He does not discuss subsequent key papers on the road to our embrace of snRNPs as agents of mRNA splicing from the laboratories of Joan Steitz and Reinhard Luhrmann a few years later that clinched and expanded the story. Again, there are places in the book where the author's history of science intent falls off a little. That said, the historical sweep is in general done so authoritatively that these quibbles are minor indeed.

In Chapter 5, the author takes up the control of mRNA expression in eukaryotic cells, a topic some pre-publication reviewers of the book (including me) thought veered too far off into broader reaches of signal transduction and cell biology. Even after reviewers' input, I thought this chapter could have been a bit shorter and more focused on RNAmediated regulation. To his credit, Darnell presents microRNAs and RNA interference in the chronological order of their discovery (which many authors unknowingly reverse) and, more au courant, he managed to get in some key advances on long noncoding RNAs that were breaking just when the book was going to press. I also think we can cut the author some slack in that he left the RNA field in favor of signal transduction 20 years ago, and his zeal for the congruence of these two domains of eukaryotic regulatory biology is by no means ill-considered.

In the final chapter, the author takes up RNA chemistry and RNA evolution, not only as we can view the reactions that certain synthetic RNAs can perform (or be reactants in) in the laboratory, but also as we can infer the geological history of plausible players like hydrogen cyanide and formaldehyde as well as the chemical potential of phosphorous oxyanions throughout pre- and post-biotic eras. Others had expounded on why phosphorous was chosen for, inter alia, the condensation reactions that build the backbone of nucleic acids (Todd 1959; Bretscher 1980; Westheimer 1987), but Darnell presents insights into RNA catalysis that, while not his ken, are as well developed, in a didactically useful way, as any I have seen. In this chapter, one again gets the sense of the author's impressive erudition, bridging evolu- 
tion, RNA science, and the history of molecular biology. I would have expected inclusion of the work of Albert Eschenmoser, seminal and cogent in my opinion, but this is a minor point, and the author was not intending a deep chemical biology (or "chemical pre-biology") treatment of RNA in the origin and evolution of life on Earth.

As to production and marketing, the dust jacket is artistically lovely but shows a most unbelievable RNA molecule, viz., with $0 \%$ secondary structure. But this blemish is compensated on the back cover flap by one of the best photos of the author ever taken. I disliked the index as to how the RNA heading was subdivided (one has to see it to grasp its wobbly dimensions). The quality of half-tone figure reproduction is excellent.

So, what we learn from this book is that it takes large, middle-sized, and small RNAs for cells to work. RNA got to be metabolism and genes, got to be machines that regulate RNA genes, and later adapted to reading DNA genes. But that would be an unduly prosaic take on this wonderful book. The story it tells is far more evocative and epochal than can be captured in a reviewer's closing statement. My take is simple: No one could have written the eukaryotic RNA story as well as Jim Darnell. Matt Meselson, Sydney Brenner, Art Pardee, François Jacob, or Jim Watson could have written the RNA story up to a point, 1961, but not into the eukaryotic era. How wonderful that Jim Darnell has done so, and how important it is that he has written with a pen aimed both at the workings of extant cells but also mindful of the RNA roots in the evolutionary path that has brought life on Earth to its present time. RNA comes to us from the ages. This book is for us now, in our time. It will not last for as long as RNA has or will, but it will not be supplanted by as glorious a book on RNA anytime soon.

\section{ACKNOWLEDGMENTS}

Early in my attempts to become more educated on the epistemology of molecular biology, I was warmly encouraged by the late Horace Judson, to whom this review is dedicated. The author's research is supported by the US National Science Foundation.

\section{REFERENCES}

Brenner S, Jacob F, Meselson M. 1961. An unstable intermediate carrying information from genes to ribosomes for protein synthesis. Nature 190: $576-581$.

Bretscher M. 1980. Why is phosphate so useful? Mol Biol Biochem Biophys 32: 195-196.

Crick F. 1988. What mad pursuit. Basic Books, New York.

Dubos R. 1976. The professor, the institute and DNA. Rockefeller University Press, New York.

Echols H. 2001. Operators and promoters: The story of molecular biology and its creators (ed. CA Gross). University of California Press, Berkeley, CA.

Gesteland RF, Cech TR, Atkins JF. 2006. The RNA world, 3rd ed. Cold Spring Harbor Laboratory Press, Cold Spring Harbor, NY.
Gros F, Hiatt H, Gilbert W, Kurland CG, Risebrough RW, Watson JD. 1961. Unstable ribonucleic acid intermediate revealed by pulse labeling of Escherichia coli. Nature 190: 581-585.

Harris H. 1963. Nuclear ribonucleic acid. Prog Nucleic Acid Res Mol Biol 2: 19-59.

Holmes FR. 2001. Meselson, Stahl and the replication of DNA. Yale University Press, New Haven.

Jacob F. 1988. The statue within. Cold Spring Harbor Laboratory, Cold Spring Harbor, NY.

Judson H. 1979. The eighth day of creation. Simon and Schuster, New York.

Kay L. 1993. The molecular vision of life. Caltech, The Rockefeller Foundation and the rise of the new biology. Oxford University Press, New York.

Kay L. 2000. Who wrote the book of life? A history of the genetic code. Stanford University Press, Stanford, CA.

Lerner MR, Boyle JA, Mount SM, Wolin SL, Steitz JA. 1980. Are snRNPs involved in splicing? Nature 283: 220-224.

Lewin B. 1980. Gene expression. Eucaryotic chromosomes, 2nd ed. Wiley, New York.

Maddox B. 2002. Rosalind Franklin. The dark lady of DNA. HarperCollins, New York.

Munroe SH, Pederson T. 1981. Messenger RNA sequences in nuclear ribonucleprotein particles are complexed with protein as shown by nuclease protection. J Mol Biol 147: 437-449.

Nomura M, Hall BD, Spiegelman S. 1960. Characterization of RNA synthesized in E. coli after bacteriophage T2 infection. J Mol Biol 2: 306-326.

Olby R. 1974. The path to the double helix. The discovery of DNA. Dover, New York.

Olby RC. 2009. Francis Crick. Hunter of life's secrets. Cold Spring Harbor Laboratory Press, Cold Spring Harbor, NY.

Pardee AB. 1958. Experiments on the transfer of information from DNA to enzymes. Exp Cell Res Suppl 6: 142-151.

Pederson T. 1974. Proteins associated with heterogeneous nuclear RNA in eukaryotic cells. J Mol Biol 87: 163-183.

Pederson T. 2010. Mahlon Hoagland. Biographical Memoirs of the National Academy of Sciences. National Academy of Sciences Press, Washington, DC.

Pederson T. 2011. Paul C. Zamecnik. Biographical Memoirs of the National Academy of Sciences. National Academy of Sciences Press, Washington, DC.

Pederson T, Davis NG. 1980. Messenger RNA processing and nuclear structure: isolation of nuclear ribonucleoprotien particles containing $\beta$-globin messenger RNA precursors. J Cell Biol 87: 47-54.

Pederson T, Munroe SH. 1981. Differential nucleoprotein structures of globin messenger RNA sequences in nuclear and polyribosomal RNP particles. J Mol Biol 150: 509-524.

Petermann ML. 1964. The physical and chemical properties of ribosomes. Elsevier, New York.

Sirlin JL. 1972. Biology of RNA. Academic Press, New York.

Steitz JA, Kamen RD. 1981. Arrangement of 30 S hnRNP nuclear ribonucleoprotein proteins on polyoma virus late nuclear transcripts. Mol Cell Biol 1: 1-34.

Todd A. 1959. Some aspects of phosphate chemistry. Proc Natl Acad Sci 49: 1389-1397.

Ullmann A. 2003. Origins of molecular biology. A tribute to Jacques Monod. American Society for Microbiology, Washington, DC.

Westheimer FH. 1987. Why nature chose phosphates. Science 235: $1173-1178$.

Yarus M. 2010. Life from an RNA world. The ancestor within. Harvard University Press, Cambridge, MA.

Thoru Pederson, Department of Biochemistry and Molecular Pharmacology, University of Massachusetts Medical School, Worcester, MA01605, USA; e-mail: thoru.pederson@umassmed.edu. 

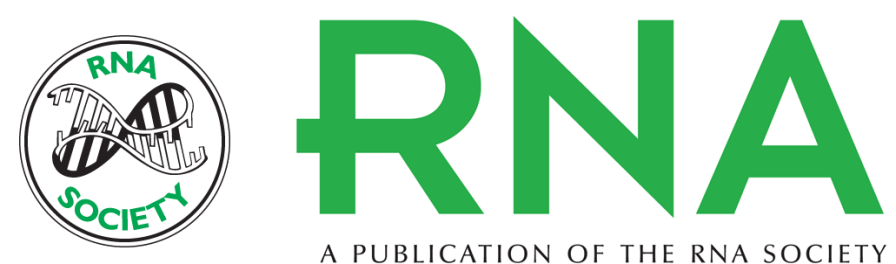

A PUBLICATION OF THE RNA SOCIETY

\section{RNA: Life's Indispensable Molecule, by James E. Darnell. 2011. Cold Spring Harbor Laboratory Press. ISBN: 978-1-936113-19-4.}

Thoru Pederson

RNA 2011 17: 1771-1774 originally published online August 24, 2011

Access the most recent version at doi:10.1261/rna.2939711

\section{References This article cites 14 articles, 3 of which can be accessed free at: http://rnajournal.cshlp.org/content/17/10/1771.full.html\#ref-list-1}

License Email Alerting
Service 